\title{
Determining Factors Affecting Audit Opinion: Evidence from Turkey
}

\author{
Ahmet Özcan \\ Assistant Professor of Accounting, Faculty of Business, Management Information Systems \\ Adana Science and Technology University, Turkey \\ E-mail: aozcan@adanabtu.edu.tr
}

Received: July 14, 2016 Accepted: July 30, 2016 Published: August 04, 2016

doi:10.5296/ijafr.v6i2.9775 URL: http://dx.doi.org/10.5296/ijafr.v6i2.9775

\begin{abstract}
The main objective of this study is to construct a model based on financial and non-financial variables to identify factors affecting audit opinions. To examine the usefulness of financial and non-financial variables in distinguishing between firms with an unqualified audit opinion and firms with an adverse audit opinion, the relationship that exists between independent variables and the type of audit opinion is investigated through logit model. The findings of empirical analysis shed light on the relationship between firm specific factors and the type of audit opinion. The results of logit analysis suggest that an unqualified audit opinion is issued for firms that have a higher liquidity, profitability, operational efficiency, growth rate, percentage of outside board members and low debt to total asset ratio. The results of empirical analysis demonstrate that financial and non-financial variables can be significantly useful in distinguishing between firms with an unqualified audit opinion and firms with an adverse audit opinion. Additionally, the inclusion of non-financial variables, age and the percentage of outside board members, significantly improves the performance of empirical model.
\end{abstract}

Keywords: Audit opinion, Financial and non-financial variables, Going- concern assumption 


\section{Introduction}

Financial statements and their analysis reflect quantified information about firms' financial position and performance. This reflection is extremely necessary for investors, creditors, stockholders, government agencies and suppliers in understanding the firm's financial health and financial performance on liquidity, profitability, operational efficiency and leverage grounds. Such information is heavily needed for any economic decisions. The reliability and accuracy of financial statements disseminated by firms have significant effects on the efficiency of financial markets. There are various factors that influence the reliability and accuracy of financial statements. Corporate governance mechanisms, corporate culture, internal control systems, and industry in which a firm operates are among the most important factors. Firms are expected to employ the appropriate corporate governance mechanisms, and internal control systems in order to boost the quality of financial statements.

Auditing activity is one of the most debated topics in today's business environment. Audit opinions have a prominent role in ensuring success of long run efficiency of the economy. Anderson et al. (2004) state that creditors, investors, stockholders, government agencies, suppliers and labor unions use audit opinions to get information about firms' financial health and viability. Firth (1978) and O'Reilly (2009) concluded that information presented by audit reports massively influences investors' decisions. Libby (1979) stated that audited financial statement is crucially important for creditors in the evaluation of a firm's creditworthiness. Therefore, many banks and credit unions demand audited financial statements from firms to ensure the accuracy of accounting information included in financial statements (Durendez, 2003). The audited financial statements significantly mitigate the uncertainty associated with a firm's financial position. Moreover, Jensen and Meckling (1978) support the assertion that auditing activity increases the value of reporting entity. Zimmermann and Watts (1983) state that bankruptcy laws and changes in the audit market enhance the development of independent auditing activity. The auditing is also an important monitoring activity, as Erdogan (2002) put it, that prevents tax evasion and tax fraud in a country's economy.

Audit opinion is the final product of the auditing process. At the end of auditing process, auditors disclose their opinions to the public. Standard unqualified audit opinion states that financial statements prepared by the firm are fairly presented inconformity with accounting standards. Adverse audit opinion is issued when financial statements prepared by the firm are not fairly presented, and material misstatements have significant adverse impacts on the financial statements (Johnstone et al. 2013).

In recent decades, the information presented by audit reports has grabbed the attention of academicians and practitioners in Turkey, as in the most of emerging countries. Global credit crunch and geopolitical problems have had adverse impacts on firms listed in Borsa Istanbul since 2008. During this period, the competitiveness and profitability of firms listed in Borsa Istanbul have deteriorated. Audit opinions facilitate tracing impacts of those problems on firms listed in Borsa Istanbul. In this respect, the study on Turkish case yield valuable results that can help financial statement users. 


\section{MInstitute Macrothink $_{\text {Int }}$}

International Journal of Accounting and Financial Reporting

ISSN 2162-3082

2016, Vol. 6, No. 2

Over the past years, numerous research studies have analyzed factors that affect audit opinion. The different findings reached by these studies have motivated further studies. The majority of studies have focused on developed markets and there are few studies that analyzed factors affecting the auditor's opinion for developing markets. This study seeks to analyze factors that affect auditor's opinion in Turkey.

In this study, logistic regression model is employed to analyze the usefulness of publicly available information to identify audit opinion. The logit model provides information regarding the likelihood of receiving an unqualified audit opinion and adverse audit opinion. This empirical model is expected to serve as a decision-making tool that can be used by auditors when forecasting what type of opinion would be issued by other auditors in the same situation. The empirical model employs financial and non-financial variables and differs from previous ones due to employing financial and non-financial variables together. Non-financial variables, age and the percentage of outside board members, are considered important factors affecting the firm's financial reporting process. Financial variables used in the model measure the firm's profitability, liquidity and operational efficiency from different perspectives.

The rest of this paper is structured as follows. Section 2 briefly outlines the audit industry in Turkey. Section 3 presentsthe past literature on the impact of the financial and non-financial factors on the auditor's opinion. Section 4discusses the research design and data. Section 5 puts forward the results of empirical analysis and discussions. The final section concludes the paper and suggests for the future research studies.

\section{The Audit Industry in Turkey}

In Turkey, Public Oversight, Accounting and Auditing Standards Authority is the primary authority that issues Turkish Auditing Standards and regulates the audit industry.In performing their duties, auditors use both Turkish Auditing Standards and International Standards on Auditing (ISA) that provide a detailed outline to improve the audit quality. According to Turkish Auditing Standards, the auditor should possess the required technical experience in accounting to accurately analyze the operations of firms, examine all accounts and the management of the firm as required by accounting and auditing standards and ensure that all accounts are properly recorded in accordance with financial reporting standards. Additionally, the auditor should determine whether the firm has an effective internal control system and a member of board of directors has violated commercial code, firm policies and procedures.

ISA 570 states that auditors should evaluate the ability of a firm to continue as a going concern. Generally speaking, the financial and operational problems threaten the going concern status of firms. Within this perspective, the major responsibilities of auditors are to identify and report potential financial and operational problems. Financial and operational analysis are the most relevant to the going concern concept, but they are related to all dimensions of auditing profession.

The size of audit industry in Turkey has tremendously increased as a result of sustainable economic growth during the last decade. As the volume of foreign direct investment increases 


\section{Mll Macrothink}

International Journal of Accounting and Financial Reporting ISSN 2162-3082 2016, Vol. 6, No. 2

and Turkish national stock market attracts many foreign investors, Turkish auditing practices become much more important than before. As being a role model for other emerging countries, the developments in Turkish auditing practice is carefully monitored by other emerging countries. There are ninety-one audit firms in Turkey and this number increases every year. The big four audit firms (PwC, Deloitte, Ernst \& Young, and KPMG) hold approximately $65 \%$ of audit market share in Turkey. The significant high levels of trust in financial statement audit is considered a primary reason for this huge market share.

New Turkish Commercial code that came into effect in 2012 has prominent impacts on audit industry and reshapes audit practices. According to Turkish Commercial Code, there are three types of auditing; operational auditing, independent auditing and special auditing. Operational auditors audit the establishment of business entities, spin-offs, the change in the form of business entities, merger cases, issuance of common stock and marketable securities, capital increase and decrease. New Turkish Commercial Code introduced the term of ${ }^{\circ}$ special audit'. Special auditing is conducted under certain circumstances such as the probability of fraud alleged and investigation of accounting irregularities. Special audits is expected to support the minority rights in firms. Special auditing is one of the high value added activities in the Turkish business environment.

\section{Literature Review and Hypothesis Development}

In this part of the study, previous studies that investigated the factors affecting the audit opinion are presented. There has been a considerable research effort for the development of the quantitative models that aim to identify factors affecting the audit opinion. Previous studies prove that quantitative models are very useful in identifying factors that affect the audit opinion.

Laitinen and Laitinen (1998) developed a model by using accounting variables to identify factors affecting the auditor's opinion in Finland. The results imply that lower growth rate and low profitability decrease the likelihood of receiving an unqualified audit opinion and the unqualified audit opinion is positively associated with the number of employees and the share of equity in the balance sheet. Additionally, they also emphasized that this model may give signals to the auditors to identify problems that may be difficult to be uncovered by traditional auditing methods.Based on a sample that includes one hundred firms operating in Greece, Spathis (2003) employed a logistic regression model that can be used to identify factors affecting the audit opinion. The empirical findings reveal that the audit opinion is strongly associated with financial information such as the liquidity level of firms. The model built with financial and non-financial information correctly classifies all sample firms with an accuracy of $78 \%$.

Kirkos et al. (2007) employed three different data mining methods; decision tree, neural networks, and Bayesian belief network, to distinguish between the unqualified audit opinion and the qualified audit opinion. A model is constructed based on 26 financial ratios. The empirical results reveal that financial distress measured by Altman Z-score is closely related with the audit opinion and firms that show low profitability receive qualified opinions, confirming the findings of previous research studies (Loebbecke et al., 1989; Laitenen and 


\section{MInstitute Mach $^{m}$}

International Journal of Accounting and Financial Reporting

ISSN 2162-3082

2016, Vol. 6, No. 2

Laitenen 1998). They also stated that these models can be a useful analytical tool for auditors when assessing the firms' financial position and performance.

Citron and Taffler (1992) stated that firms facing financial distress are likely to receive adverse audit opinion and smaller audit firms do not issue lower rate of adverse audit opinions than large audit firms. Mutchler (1985) analyzed the relationship that exists between the type of audit opinion and publicly available information. He used discriminant analysis based on accounting ratios to predict audit opinion and concluded that accounting ratios appear to be useful in predicting audit opinion. Dopuch et al. (1987) developed a probit model based on financial and market variables to forecast the audit opinion and claimed that current year loss, industry return, and the change in the ratio of total liabilities to total assets play an important role in prediction of the audit opinion. Anandarajan and Anandarajan (1999) investigated the effectiveness of three prediction models for the audit opinion. Artificial neural networks, expert systems and multiple discriminant analysis are employed as a prediction model. In this study, fourteen independent variables are used and the sample consists of ninety firms listed in New York Stock Exchange and American Stock Exchange. They suggested that artificial neural network provides greater decision usefulness than other methods in predicting the type of audit opinion. It is also noteworthy that many critical qualitative variables that may affect the audit opinion are not incorporated into these models.

Keasey et al. (1988) established a logistic regression model to determine factors affecting the audit opinion by using auditor variables, organizational and financial variables. They concluded that firms audited by a large audit firm and firms which have declining earnings, a long audit report lag and few directors are more likely to receive a qualified audit opinion. Maggina and Tsaklanganos (2011) employed discriminant analysis and logit model to identify factors related to the audit opinion. In the empirical analysis, eleven accounting ratios are used and the final sample includes 275 firms. According to the results of logit model, the percentage of correctly classified firms is above $95 \%$. They also asserted that the models can also be used to identify financially troubled firms.

Caramanis and Spathis (2006) examined whether financial and non-financial factors affect audit qualifications. They created a logistic regression model based one a sample that consists of 185 firms and stated those financial factors such as operating margin to total assets and the current ratio are significantly related with the audit opinion. The logit model they developed correctly classified sample firms with an accuracy of 90\%.Nahandi et al. (2013) investigated the usefulness of cash flow statement in predicting audit opinion. The data used in the empirical analysis comes from the firms listed in the Tehran Stock Exchange from 2003 to 2010. Five cash flow ratios are employed as the independent variable and the auditor's opinion is a dependent variable in the study. They concluded that cash flow ratios are among prominent factors affecting the audit opinion and there is a positive correlation between the amount of cash flow and the likelihood of receiving an unqualified audit reports.

Auditor's independence is one of the most hotly debated issues in the general economic environment because of massive accounting scandals ( $\mathrm{Li}, 2009)$. Non-audit services such as bookkeeping, internal auditing, the design and implementation of accounting information 


\section{Mll Macrothink}

International Journal of Accounting and Financial Reporting ISSN 2162-3082 2016, Vol. 6, No. 2

systems provided by the audit firms may impair auditor's independence. Sarbanes- Oxley Act that came into effect in 2002 has limited the scope of non-audit services in order to enhance auditor independence. Zhang et al. (2007) argued that the strong economic bond that exists between audit firm and audit client makes auditors to ignore internal control weaknesses. Ahadiat (2011) stated that auditors are more likely to issue unqualified opinion when a significantly higher level of non-audit services are provided by the audit firm to the audit client.

The presence of accounting conservatism provides confidence to the financial market participants. Amir et al. (2009) and Lim (2011) stated that independent auditors should use a high level of accounting conservatism policy in the auditing process and the use of accounting conservatism significantly increases the quality of financial reporting. Non-audit services provided by audit firm to the audit client may affect accounting conservatism. Crockett and Ali (2015) investigated whether strong economic bond between audit firms and audit clients affects accounting conservatism. They concluded that the economic bond between audit firms and audit clients has no significant impact on the accounting conservatism for Australian firms. Auditing standards suggest that auditors should closely analyze the ability of a firm to meet its debt obligations. The volume and type of debt obligations are among major considerations for auditors when assessing going concern status. Yao and Liu (2010) stated that the occurrence of debt-related events prevents firms from receiving the going-concern opinion. Chen and Church (1992) found that the default status of firms is useful in explaining the type of audit opinion.

As previous research studies have provided mixed results and failed to correctly identify factors affecting audit opinion, further research studies are needed to identify factors affecting audit opinion. Financial and non-financial variables are vital issues in identifying audit opinion. The correct use of non-financial and financial variables improves the reliability of empirical model that would serve a critical analytical tool for auditors. Motivated by these concerns, the following hypothesis is to be tested:

Hypothesis 1: Financial and non-financial measures are associated with the audit opinion.

\section{Research Design}

\subsection{Data and Sample}

This section presents the characteristics of the sample data. The data used in the empirical analysis covers the period from 2005 to 2014. To be included in the sample, a firm must be listed on Borsa İstanbul, operate in the manufacturing industry and its audited financial statements must be available in the website of public disclosure platform. Firms operating in the financial industry are not included in the sample since the structures of financial statements of these firms are significantly different. The firms that received the unqualified audit opinion are matched with firms that received the adverse audit opinion. To determine independent variables, previous studies that examined factors affecting the audit opinion are meticulously considered. Keasey et al. (1988), Spathis (2003), Laitenen and Laitenen (1998), Dopuch et al. (1987) and Kirkos et al. (2007) include recommended accounting variables for 


\section{Mll Macrothink}

International Journal of Accounting and Financial Reporting

the quantitative model.

Table 1 exhibits industry classification of sample firms included in the empirical analysis. As can be seen from Table 1, the most heavily represented industry in the sample is fabricated metal products, machinery and equipment $(33 \%)$ followed by chemicals, petroleum rubber and plastic products (19\%). The least represented industry in the sampleis wood products $(7 \%)$.

Table 1. Industrial Classification of Sample Firms

\begin{tabular}{|l|l|l|}
\hline Sectors & Number of Firms & Percentage \\
\hline Food, Beverage and Tobacco & 15 & $8 \%$ \\
\hline Non- Metallic Mineral Products & 18 & $10 \%$ \\
\hline $\begin{array}{l}\text { Fabricated Metal Products, Machinery and } \\
\text { Equipment }\end{array}$ & 59 & $33 \%$ \\
\hline Chemicals, Petroleum Rubber and Plastic Products & 35 & $19 \%$ \\
\hline Basic Metal Industries & 18 & $10 \%$ \\
\hline Paper and Paper Products, Printing and Publishing & 23 & $7 \%$ \\
\hline Wood Products & 12 & $100 \%$ \\
\hline Total & 180 & $13 \%$ \\
\hline
\end{tabular}

Data used in empirical analysis are collected from financial statements publicly disclosed by sample firms. The sample consists of one hundred eighty firms listed on Borsa İstanbul. Ninety firms that received the unqualified and ninety firms that received the adverse audit opinion are included in the sample. It is worth mentioning that pairings were made on the basis of industry classification and asset volume.

\subsection{Empirical Model and Variables}

The primary objective of using financial and non-financial variables in the logit model is to summarize sample firms' financial health and performance. In the logit model, ninety firms that received anunqualified audit opinion and ninety firms that received an adverse audit opinion are included in the sample. To analyze the usefulness of financial and non-financial variables in distinguishing between firms that received an unqualified audit opinion and firms that received an adverse audit opinion, the relationship that exists between independent variables and the type of audit opinion is investigated through logit model. 


\section{MlMacrothink}

International Journal of Accounting and Financial Reporting

ISSN 2162-3082

2016, Vol. 6, No. 2

The list of variables used in the empirical analysis is presented in Table 2. The set of independent variables consists of financial and non-financial measures. Financial measures are grouped into four categories: (1) liquidity ratios,(2) profitability ratios, (3) operating efficiency ratios and (4) solvency ratio. Liquidity position of the sample firms is measured by current ratio and cash ratio. Spathis (2003) and Reynolds and Francis (2001) stated that the likelihood of receiving an unqualified audit opinion increases if the liquidity of the firm increases. Profitability of the sample firms is measured by return on assets, return on equity and profit margin. Loebbecke et al. (1989), Laitenen and Laitenen(1998) and Beasley (1999) support the assertion that the firms that received the unqualified audit opinion are more profitable than firms that received the adverse audit opinion. The ratio of debt to total assets, a solvency ratio, is included in the empirical model. The ratio of debt to total assets evaluates the long term sustainability of the firm's operations. A high ratio of debt to total assets means that the firm relies more on external funds rather than shareholders' equity to finance its assets. Laitenen and Laitenen (1998) and Reynolds and Francis (2001) report that a higher proportion of external funds significantly decreases the likelihood of receiving the unqualified audit opinion. Asset turnover ratio and equity turnover ratio are included in empirical analysis to capture the effects of the firm's operational efficiency on the audit opinion. It is expected that high operational efficiency increases the likelihood of receiving the unqualified audit opinion.

Age, a non-financial variable, is one of the factors affecting the audit opinion. The longer time a firm's common stock has been traded in the stock markets, the more likely it satisfies the requirements for the unqualified audit opinion. A positive and significant coefficient on age would confirm this prediction. In this study, growth is the five year average percentage change in the firm's total assets. Changes in the firms' total assets can be helpful in predicting the type of audit opinion. Laitenen and Laitenen (1998) stated that the firms that received the unqualified audit opinion generally show higher growth rate than firms with adverse audit opinion. Auditors are potentially concerned with the structure of board of directors that have considerable impacts on financial reporting process. Keasey et al. (1988) found that firms that received the adverse audit opinion have a low percentage of outside board members. The following logit model that aims to identify factors affecting the audit opinion is developed. The logit model also enables us to classify sample firms based on financial and non-financial variables.

Audit Opinion: $\alpha+\beta_{1}$ Age $+\beta_{2} \%$ Outside $+\beta_{3}$ Growth $+\beta_{4}$ Current Ratio $+\beta_{5}$ Cash Ratio $+\beta_{6}$ ROA $+\beta_{7}$ ROE $+\beta_{8}$ Profit Margin $+\beta_{9}$ Asset Turnover Ratio $+\beta_{10}$ Equity Turnover Ratio $+\beta_{11}$ Debt to Total Assets $+\varepsilon$ 


\section{Macrothink}

International Journal of Accounting and Financial Reporting ISSN 2162-3082 2016, Vol. 6, No. 2

Table 2. Variable Descriptions

\begin{tabular}{|c|c|}
\hline \multicolumn{2}{|l|}{ Dependent Variable } \\
\hline Audit opinion & $\begin{array}{l}\text { Coded } 0 \text { if the firm received the unqualified audit opinion and } 1 \\
\text { if the firm received the adverse audit opinion }\end{array}$ \\
\hline \multicolumn{2}{|l|}{ Independent Variables } \\
\hline \multicolumn{2}{|l|}{ Non-Financial } \\
\hline Age & $\begin{array}{l}\text { The number of years the firm's common stock has been traded on } \\
\text { Borsa İstanbul }\end{array}$ \\
\hline$\%$ Outside & The percentage of outside members on the board of directors \\
\hline \multicolumn{2}{|l|}{ Financial } \\
\hline Growth & Five year average percentage change in the firm's total assets \\
\hline Liquidity ratios & Current ratio, cash ratio \\
\hline Profitability ratios & Return on assets, return on equity, profit margin \\
\hline $\begin{array}{l}\text { Operating efficiency } \\
\text { ratios }\end{array}$ & Asset turnover ratio, equity turnover ratio \\
\hline Solvency ratio & Debt to total assets \\
\hline
\end{tabular}

\section{Empirical Results}

\subsection{Descriptive Statistics}

In this section of study, the descriptive statistics of variables are given to provide basic characteristics of analyzed data. Table 3 reports univariate tests and descriptive statistics of variables used in the logit model. 
Table 3. Descriptive Statistics

\begin{tabular}{|c|c|c|c|c|c|c|}
\hline & \multicolumn{2}{|l|}{ Mean } & \multicolumn{2}{|c|}{ Standard Deviation } & \multirow[b]{2}{*}{ 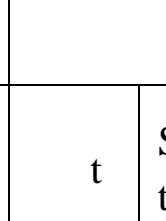 } & \multirow[b]{2}{*}{$\begin{array}{l}\text { Sig. } \\
\text { tailed) }\end{array}$} \\
\hline & Unqualified & Adverse & Unqualified & Adverse & & \\
\hline Age & 19.30 & 10.80 & 8.85 & 5.57 & $8.156^{*}$ & 0.000 \\
\hline$\%$ Outside & 0.310 & 0.250 & 0.070 & 0.230 & $2.254^{*}$ & 0.026 \\
\hline Growth & 0.120 & 0.018 & 0.100 & 0.130 & $6.227^{*}$ & 0.000 \\
\hline Current Ratio & 2.386 & 1.056 & 1.793 & 1.068 & $5.475^{*}$ & 0.000 \\
\hline Cash ratio & 0.859 & 0.126 & 2.057 & 0.338 & $3.280^{* *}$ & 0.001 \\
\hline ROA & 0.057 & -0.036 & 0.090 & 0.243 & $3.326^{*}$ & 0.001 \\
\hline ROE & 0.111 & -0.182 & 0.235 & 0.410 & $5.425^{*}$ & 0.000 \\
\hline Profit Margin & 0.107 & -0.363 & 0.334 & 1.139 & $3.834^{*}$ & 0.002 \\
\hline $\begin{array}{ll}\text { Asset } & \text { turnover } \\
\text { ratio } & \end{array}$ & 0.923 & 0.504 & 0.452 & 0.492 & $5.700^{* *}$ & 0.000 \\
\hline $\begin{array}{l}\text { Equity turnover } \\
\text { ratio }\end{array}$ & 2.054 & 0.323 & 1.690 & 2.020 & $13.906^{*}$ & 0.000 \\
\hline $\begin{array}{l}\text { Debt to total } \\
\text { assets }\end{array}$ & 0.433 & 1.101 & 0.205 & 1.656 & $-3.659^{* * *}$ & 0.004 \\
\hline
\end{tabular}

Notes:

* Denotes significance at the $10 \%$ level.

** Denotes significance at the $5 \%$ level.

*** Denotes significance at the $1 \%$ level.

The results of univariate tests are presented in the last column. Univariate tests yield precious information about the variables used in the empirical analysis. The univariate tests indicate that financial and non-financial variables may be helpful in determining the audit opinion. 


\section{Mll Macrothink}

International Journal of Accounting and Financial Reporting

ISSN 2162-3082

2016, Vol. 6, No. 2

The results reveal that age, $\%$ outside, growth, current ratio, ROA, ROE, profit margin and equity turnover ratio are significantly different for both groups at the 0.1 level. There are significant differences in the means between firms that receive the unqualified audit opinion and firms that receive the adverse audit opinion at the 95\% confidence level for the cash ratio and asset turnover ratio. Debt to total assets is the only statistically significant variable at the 0.01 level. The mean value of liquidity ratios, current ratio and cash ratio, is higher for firms that received the unqualified audit opinion than firms that received the adverse audit opinion indicating the ability of firms that received the unqualified audit opinion to pay their short term obligations.

The mean value of profitability ratios, ROA, ROE, and profit margin, is higher for firms with the unqualified audit opinion than firms with the adverse audit opinion reflecting that firms with the unqualified audit report are much more profitable than firms with the adverse audit opinion. Operational efficiency measures, asset turnover ratio and equity turnover ratio, also help auditors to accurately issue audit opinion. Firms with low asset turnover ratio and equity turnover ratio are likely to receive the adverse audit opinion.

The mean value of solvency ratio for firms that received the adverse audit opinion is higher than that of firms that received the unqualified audit opinion, indicating that firms relying more on shareholders' funds receive the unqualified audit opinion. The results also reveal that higher growth rate and percentage of outside members increase the likelihood of receiving the unqualified audit opinion. Even though the output of correlation matrix is not reported, there is no multicollinearity problem among empirical variables. Considered altogether, the results of univariate tests suggest that the financial and non-financial variables are useful in distinguishing between firms that received the unqualified audit opinion and firms that received the adverse audit opinion.

\subsection{Empirical Results of Logistic Regression Analysis}

This paper analyzes financial and non-financial variables at the aggregate level, that is why logistic regression model is selected for the empirical analysis. In the logit model, the interaction effects of variables can also be analyzed. Table 4 presents the results of logistic regression model. As can be seen from the empirical results, the logit model yields valuable information for audit risk assessments. The results of logit model reveal that the relationship between financial and non-financial variables and the type of audit opinion is statistically significant $\left(\chi^{2}=177.23, p<0.000\right)$. The strength of relationship that exists between dependent and independent variables is $\mathrm{R}$-squared $=0.710$, implying a strong relationship between independent variables and type of audit opinion. Table 4 shows that profit margin is only statistically significant variable at the 0.1 level, ROE and asset turnover ratio are statistically significant at the 0.05 level and age, \% outside, growth, and debt to total assets are statistically significant at the 0.01 level. The coefficients on current ratio, cash ratio and return on assets are not statistically significant. However, these non-significant variables in the empirical model are considered useful indicators at the aggregate level. 


\section{MlMacrothink}

International Journal of Accounting and Financial Reporting

ISSN 2162-3082

2016, Vol. 6, No. 2

The results of logistic regression analysis reveal that a firm is more likely to receive the unqualified audit opinion if the number of years the its common stock has been traded on stock market is high. The negative coefficient on the age implies that age is a positive factor that increases the likelihood of receiving the unqualified audit opinion. Similarly, the negative coefficient on percentage of outside board members indicates that a firm is more likely to receive the unqualified audit opinion when the percentage of outside board members is high, confirming the findings of Keasey et al. (1988). In other words, the inclusion of outside board members significantly enhances the financial accounting process.

The coefficient on growth is statistically significant negative which suggests that a firm is more likely to receive the adverse audit opinion when the growth rate is low. This is consistent with the findings of Laitinen and Laitinen (1998) and Gaganis et al. (2007). In other words, firms with high growth rate are much more likely to comply with International Financial Reporting Standards. The negative coefficients for current ratio and cash ratio suggest that firms that received the adverse audit opinion suffer from low liquidity, verifying the findings of previous studies (Gaganis et al., (2007), Reynold and Francis (2001), Mutchler (1985), Koh (1991) and Spathis et al.(2003). The coefficients on liquidity ratios are not statistically significant, contrary to findings of previous studies. The results of logit analysis suggest that profitability ratios, return on assets, return on equity, and profit margin, play a vital role in predicting the type of audit opinion. The negative coefficients on return on assets, return on equity and profit margin mean that auditors are likely to issue adverse audit opinion when the audit client has weak financial performance. This result parallels with the findings of Dopuch et al. (1987), Loebbecke et al. (1989), Laitinen and Laitinen (1998), and Spathis et al. (2003) who found that a firm with low profitability is likely to receive an adverse audit opinion.

The negative coefficients on asset turnover ratio and equity turnover ratio imply that firms suffering from low operational efficiency are more likely to receive adverse audit opinion. In other words, unqualified audit opinions are issued for the firms that efficiently utilize shareholders' equity and total assets in generating revenue.

Taken together, the logit model indicates that anadverse audit opinion is issued for firms that have low liquidity, low profitability, low operational efficiency, low growth rate, low percentage of outside board members and high leveraged ratios. The logit model depicted in Table 4 can be helpful in identifying factors affecting the type of audit opinion. 


\section{Macrothink \\ International Journal of Accounting and Financial Reporting \\ ISSN 2162-3082 \\ 2016, Vol. 6, No. 2}

Table 4. The Results of Logistic Regression Model

\begin{tabular}{|c|c|c|c|}
\hline Independent Variables & Coefficient & Std. Error & Sig. \\
\hline Age & -0.166 & 0.044 & $0.000^{* * *}$ \\
\hline$\%$ Outside & -6.640 & 2.309 & $0.004^{* * *}$ \\
\hline Growth & -13.046 & 3.509 & $0.000^{* * *}$ \\
\hline Current ratio & -0.372 & 0.394 & 0.345 \\
\hline Cash ratio & -1.611 & 1.038 & 0.121 \\
\hline ROA & -0.644 & 0.678 & 0.342 \\
\hline ROE & -4.067 & 0.678 & $0.024^{* *}$ \\
\hline Profit margin & -1.308 & 0.706 & $0.064^{*}$ \\
\hline Debt to total assets & 0.783 & 0.266 & $0.003^{* * *}$ \\
\hline Asset turnover ratio & -1.670 & 0.806 & $0.039^{* *}$ \\
\hline Equity turnover ratio & -0.339 & 0.207 & 0.101 \\
\hline Constant & 7.042 & 1.591 & $0.000^{* * *}$ \\
\hline \multicolumn{4}{|l|}{ Summary Statistics } \\
\hline$\chi^{2}$ & 177.23 & & \\
\hline Sig. (p-value) & 0.000 & & \\
\hline
\end{tabular}

Pseudo R-squared

0.710

Notes:

*Denotes significance at the $10 \%$ level.

** Denotes significance at the $5 \%$ level.

*** Denotes significance at the $1 \%$ level. 


\section{Mll Macrothink}

International Journal of Accounting and Financial Reporting ISSN 2162-3082

Table 5 presents the classification table for the logit model. The classification results are highly satisfactory. As can be seen from the table 5, overall percent of correct classification is $93.89 \%$. It is worth noting that the overall percent of correct classification is one of the measures of the goodness of fit for the logit model. The constructed logit model incorrectly classifies only five out of 90 unqualified audit opinion and six out of 90 adverse audit opinion. The results of classification table imply that the logit model can significantly contribute to the development of an accurate model for evaluating the likelihood of receiving an unqualified audit opinion and an adverse audit opinion in Turkey.

Table 5. Classification Table

\begin{tabular}{|l|l|l|l|}
\hline & \multicolumn{2}{|l|}{ Predicted the type of audit opinion } & \\
\hline Observed & Unqualified audit opinion & Adverse audit opinion & $\begin{array}{l}\text { Percentage } \\
\text { correct }\end{array}$ \\
\hline $\begin{array}{l}\text { Unqualified audit } \\
\text { opinion }\end{array}$ & 85 & 5 & $94.44 \%$ \\
\hline Adverse audit opinion & 6 & 84 & $93.33 \%$ \\
\hline Overall percentage & & & $93.89 \%$ \\
\hline
\end{tabular}

The model proposed by this study offers significant advantages over previous models. First of all, this empirical model includes not only financial variables but also non-financial variables. Non-financial variables, age and the percentage of outside board members, included in the model contain precious information that affects the audit opinion. Moreover, the inclusion of non-financial variables mitigates the error rate in classification results. Secondly, this model outperforms most of previous models in classifying firms. The models developed by Keasey et al (1988), Spathis et al. (2004), Spathis (2003), and Koh and Killough (1990) correctly classify firms less than $90 \%$. On the other hand, overall percent of correct classification yielded by this model is above $90 \%$. High classification accuracy increases the usefulness of this model in predicting the types of audit opinion. Thirdly, financial variables included in this model measure firms' financial position and performance from many different perspectives. Additionally, these financial variables are widely used by analysts, investors, and creditors in assessing the firms' financial position and performance.

\section{Concluding Remarks}

Audit opinion is one of the critical issues for the rapidly globalizing economic environment. Investors, creditors, government agencies, suppliers and stockholders get prominent benefits from the audit opinion when assessing a firm's financial health and performance. Moreover, audit opinions are helpful guidelines for the reorganization of firm resources. An accurate and 


\section{Mll Macrothink}

International Journal of Accounting and Financial Reporting ISSN 2162-3082 2016, Vol. 6, No. 2

reliable model that identifies factors affecting the type of audit opinion would serve as a critical analytical tool for auditors when identifying and discussing problems with their clients and suggesting effective changes in policies and procedures. The empirical model proposed by this paper is important in the sense that it aids in assessing the probability of receiving an unqualified and adverse audit opinion.

Data belonging to 2005-2014 is used with auditor's opinion as a dependent variable and financial and non-financial variables as independent variables. The publicly available information of one hundred eighty firms listed in Borsa İstanbul during 2005 to 2014 are analyzed. Univariate tests are applied to analyze the relationship that exists among variables. Additionally, logistic regression is employed to determine the best predictor model. The findings of empirical analysis shed light on the relationship that exists between firm specific factors and type of audit opinion. The results of univariate analysis indicate that an unqualified audit opinion is issued for firms that have a higher liquidity, profitability, operational efficiency, percentage of outside board members, growth rate and low debt to total asset ratio. Moreover, the number of years the firm's common stock has been traded on Borsa Istanbul increases the likelihood of receiving an unqualified audit opinion.

Financial and non-financial variables are included in the logit model. Non-financial variables used in the logit model are age and the percentage of outside board members. Financial variables used in the logit model are growth, current ratio, cash ratio, ROA, ROE, profit margin, debt to total assets, asset turnover ratio and equity turnover ratio. The result of logistic regression analysis indicates that age, \% outside, growth, ROE, profit margin, debt to total assets and asset turnover ratio are statistically significant factors that distinguish the two groups of firms. Logit model yields a correct classification rate of $93.89 \%$. The higher correct classification rate shows that logit model is extremely useful in distinguishing between firms with an unqualified audit opinion and firms with an adverse audit opinion.

Future research studies can concentrate on advanced classification methods and a greater number of financial and non-financial variables. Additionally, the scope of empirical analysis can be broadened to investigate factors affecting the type of audit opinion in other developing countries.

\section{References}

Amir, E., Guan, Y. \& Livne, G. (2009). The association between auditor independence and conservatism. Working Paper, City University of London, The University of Hong Kong and London Business School.

Anandarajan, M., \& Anandarajan, A. (1999). A comparison of machine learning techniques with a qualitative response model for auditor's going concern reporting. Expert Systems with Applications, 16(4), 385-392.

Anderson, R. C., Mansi, S. A., \& Reeb, D. M. (2004). Board characteristics, accounting report integrity, and the cost of debt. Journal of accounting and economics, 37(3), 315-342. 


\section{Macrothink}

International Journal of Accounting and Financial Reporting ISSN 2162-3082 2016, Vol. 6, No. 2

Beasley, M. S., Carcello, J. V., \& Hermanson, D. R. (1999). Fraudulent financial reporting: 1987-1997. An analysis of US public companies. Committee of Sponsoring Organizations of the Treadway Commission.

Caramanis, C., \& Spathis, C. (2006). Auditee and audit firm characteristics as determinants of audit qualifications: evidence from the Athens stock exchange. Managerial Auditing Journal, 21(9), 905-920.

Chen, K. C., \& Church, B. K. (1992). Default on debt obligations and the issuance of goingconcern opinions. Auditing, 11(2), 30.

Citron, D. B., \& Taffler, R. J. (1992). The audit report under going concern uncertainties: an empirical analysis. Accounting and Business Research, 22(88), 337-345.

Crockett, M., \& Ali, M. J. (2015). Auditor independence and accounting conservatism: Evidence from Australia following the corporate law economic reform program. International Journal of Accounting \& Information Management, 23(1), 80-104.

Dopuch, N., Holthausen, R. W., \& Leftwich, R. W. (1987). Predicting audit qualifications with financial and market variables. Accounting Review, 431-454.

Erdoğan, M. (2011). Muhasebe, denetim ve bağımsız denetimin gerekliliği. Doğuş Üniversitesi Dergisi, 3(1), 51-63.

Firth, M. (1978). Qualified audit reports: their impact on investment decisions. Accounting Review, 642-650.

Gaganis, C., Pasiouras, F., Spathis, C., \& Zopounidis, C. (2007). A comparison of nearest neighbours, discriminant and logit models for auditing decisions. Intelligent Systems in Accounting, Finance and Management, 15(1-2), 23-40.

Duréndez Gómez-Guillamón, A. (2003). The usefulness of the audit report in investment and financing decisions. Managerial Auditing Journal, 18(6/7), 549-559.

Jensen, M. C., \& Meckling, W. H. (1976). Theory of the firm: Managerial behavior, agency costs and ownership structure. Journal of financial economics, 3(4), 305-360.

Johnstone, K., Gramling, A., \& Rittenberg, L. (2013). Auditing: A Risk-Based Approach to Conducting a Quality Audit. Cengage Learning.

Keasey, K., Watson, R., \& Wynarczyk, P. (1988). The small company audit qualification: a preliminary investigation. Accounting and Business Research, 18(72), 323-334.

Kirkos, E., Spathis, C., Nanopoulos, A., \& Manolopoulos, Y. (2007). Identifying qualified auditors' opinions: a data mining approach. Journal of Emerging Technologies in Accounting, 4(1), 183-197.

Koh, H. C. (1991). Model predictions and auditor assessments of going concern status. Accounting and Business Research, 21(84), 331-338. 


\section{Macrothink}

International Journal of Accounting and Financial Reporting

ISSN 2162-3082 2016, Vol. 6, No. 2

Koh, H. C., \& Killough, L. N. (1990). The use of multiple discriminant analysis in the assessment of the going-concern status of an audit client. Journal of Business Finance \& Accounting, 17(2), 179-192.

Laitinen, E. K., \& Laitinen, T. (1998). Qualified audit reports in Finland: evidence from large companies. European Accounting Review, 7(4), 639-653.

Libby, R. (1979). The impact of uncertainty reporting on the loan decision. Journal of Accounting Research, 35-57.

Loebbecke, J. K., Eining, M. M., \& Willingham, J. J. (1989). Auditors experience with material irregularities-frequency, nature, and detectability. Auditing: A Journal of Practice and Theory,9(1), 1-28.

Li, C. (2009). Does Client Importance Affect Auditor Independence at the Office Level? Empirical Evidence from Going-Concern Opinions*. Contemporary Accounting Research, 26(1), 201-230.

Lim, R. (2011). Are corporate governance attributes associated with accounting conservatism?. Accounting \& Finance, 51(4), 1007-1030.

Maggina, A., \& Tsaklanganos, A. A. (2011). Predicting audit opinions evidence from the Athens Stock Exchange. Journal of Applied Business Research (JABR), 27(4), 53-68.

Mutchler, J. F. (1985). A multivariate analysis of the auditor's going-concern opinion decision. Journal of Accounting Research, 668-682.

Nahandi, Y.B., Sarokolaei, M.A. \& Ghasemi, S., (2013). Evaluating the ability of cash flow ratios in predicting auditor's opinion. International Journal of Advanced Studies in Humanities and Social Science, 1(4), 328-343.

O'Reilly, D. M. (2009). Do investors perceive the going-concern opinion as useful for pricing stocks?. Managerial Auditing Journal, 25(1), 4-16.

Reynolds, J. K., \& Francis, J. R. (2000). Does size matter? The influence of large clients on office-level auditor reporting decisions. Journal of accounting and economics, 30(3), 375400 .

Spathis, C. T. (2003). Audit qualification, firm litigation, and financial information: an empirical analysis in Greece. International Journal of Auditing, 7(1), 71-85.

Watts, R. L., \& Zimmerman, J. L. (1983). Agency problems, auditing, and the theory of the firm: Some evidence. Journal of law and Economics, 613-633.

Yao, L. J., \& Liu, C. (2010). Are auditor's going concern opinions affected by debt-related events?.

Zhang, Y., Zhou, J., \& Zhou, N. (2007). Audit committee quality, auditor independence, and internal control weaknesses. Journal of accounting and public policy, 26(3), 300-327. 


\section{Macrothink \\ International Journal of Accounting and Financial Reporting \\ ISSN 2162-3082}

\section{Copyright Disclaimer}

Copyright for this article is retained by the author(s), with first publication rights granted to the journal.

This is an open-access article distributed under the terms and conditions of the Creative Commons Attribution license (http://creativecommons.org/licenses/by/3.0/). 